\title{
PENGARUH KECANGGIHAN TEKNOLOGI INFORMASI DAN KEMAMPUAN TEKNIK PERSONAL TERHADAP EFEKTIVITAS PENGGUNAAN SISTEM INFORMASI AKUNTANSI DI LPD KECAMATAN UBUD
}

\author{
Ni Made Kansa Dewi Putri ${ }^{1}$ \\ Ni Luh Putri Srinadi ${ }^{2}$ \\ 1,2Institut Teknologi dan Bisnis STIKOM Bali, surel: putrikansa87@gmail.com
}

\begin{abstract}
The application of an accounting information system is an important investment for a company. The use of information systems can improve the competitiveness of companies so as not excluded in their environment. This research was conducted in LPD Sub-district of Ubud. The purpose of this study is to analyze the influence of the sophistication of information technology and the ability of personal techniques on the effective use of accounting information systems. Researchers use Multiple Linear Regression Analysis as a method of data analysis, where data collection is done by observation, interviews, library research, and questionnaires. As an initial stage of the analysis will be tested for validity and reliability of the research instrument. The results showed that the sophistication of Information Technology and Personal Engineering Capabilities had a positive and significant effect on the Effectiveness of the Use of Accounting Information Systems in LPD, Ubud Gianyar District. This research will recommend the formulation of a technology-based accounting information system so that it can compete in the midst of the tight and competitive world of competition.
\end{abstract}

Keywords: Information Technology Sophistication, Personal Engineering Capabilities

\section{PENDAHULUAN}

Di era globalisasi sekarang ini, sebagian besar masyarakat semakin merasakan informasi sebagai salah satu kebutuhan pokok di samping kebutuhan akan sandang, pangan dan papan. Perubahan lingkungan yang pesat, dinamis, dan luas tersebut didukung oleh kemajuan teknologi informasi di segala bidang. Hal ini telah mendorong transformasi masyarakat tradisional menjadi masyarakat informasi. Perkembangan teknologi informasi telah membawa dampak dalam kehidupan masyarakat. Sejak ditemukannya komputer pada tahun 1955, peradaban dunia telah memasuki era informasi. Pemrosesan informasi berbasis komputer mulai dikenal orang dan hingga saat ini sudah banyak software yang dapat digunakan orang sebagai alat pengolah data untuk menghasilkan informasi. Teknologi 
informasi memungkinkan manusia untuk memperoleh informasi dari tempat yang berjauhan dalam waktu yang singkat dan dengan biaya yang murah. Selain itu teknologi informasi memunculkan suatu sistem yang bisa kita sebut sistem informasi.

Sistem informasi berperan dalam bidang akuntansi karena sistem pemrosesan informasi akuntansi berbasis komputer, banyak ditawarkan dengan tujuan untuk memberikan kemudahan bagi para akuntan untuk menghasilkan informasi yang dapat dipercaya, tepat waktu, lengkap, dapat dipahami, dan teruji. Sistem Informasi Akuntansi dapat didefinisikan sebagai sistem informasi yang merubah data transaksi bisnis menjadi informasi keuangan yang berguna bagi pemakainya. Sistem informasi akuntansi dalam sebuah organisasi bisnis menjadi sarana penting untuk meningkatkan efisiensi organisasi dan mendukung daya saing perusahaan dengan menyediakan informasi keuangan dan akuntansi bagi manajemen (Alsarayreh et al., 2011).

Kemajuan teknologi informasi dan komunikasi telah membuat sistem informasi akuntansi menjadi suatu alat penting dalam dunia bisnis yang sangat kompetitif (Ogah, 2013 dalam Ratnaningsih, 2014). Penerapan sistem informasi akuntansi merupakan investasi yang penting untuk perusahaan. Penggunaan sistem informasi dapat meningkatkan daya saing perusahaan agar tidak tersisih dalam lingkungannya (Kustono, 2011). Keefektifan sistem informasi akuntansi dapat mengukur keunggulan daya saing yang dapat diciptakan oleh perusahaan. Peningkatan efektivitas sistem informasi akuntansi memerlukan adanya peran dan partisipasi manajemen dalam mendukung implementasi dan pengembangan sistem informasi akuntansi.

Efektivitas Penggunaan Sistem Informasi Akuntansi dapat dipengaruhi oleh Kecanggihan Teknologi Informasi. Teknologi informasi merupakan aspek penting dalam organisasi (perusahaan), dimana teknologi informasi akan bernilai pada saat digunakan 
dalam organisasi untuk mencapai tujuan strategis dan operasional organisasi. Pengertian teknologi informasi dikemukakan oleh Maharsi (2000) bahwa teknologi informasi merupakan perpaduan antara teknologi komputer dan telekomunikasi dengan teknologi lainnya. Teknologi informasi dipakai dalam sistem informasi organisasi untuk menyediakan informasi bagi para pemakai dalam rangka pengambilan keputusan.Hubungan kecanggihan teknologi informasi terhadap efektivitas penggunaan sistem informasi akuntansi dapat dijelaskan dengan pemikiran bahwa sistem yang memiliki kecanggihan yang baik akan membantu perusahaan dalam menghasilkan informasi yang cepat dan akurat dalam pembuatan keputusan yang efektif.PenelitianKrisna (2018), meneliti tentang Pengaruh Kecanggihan Teknologi Informasi Terhadap Efektivitas Sistem Informasi Akuntansi dengan Dukungan Manajemen Puncak sebagai variabel pemoderasi.

Efektivitas Penggunaan Sistem Informasi Akuntansi juga dapat dipengaruhi oleh Kemampuan Teknik Personal. Kemampuan teknik personal adalah kemampuan penggunaan dalam menyelesaikan tugas-tugasnya. Semakin tinggi kemampuan teknik personal sistem informasi yang dimiliki pengguna maka pengguna semakin paham terhadap sistem informasi. Kemampuan teknik personal dapat diartikan sebagai kemampuan seseorang dalam mengoperasikan sistem dalam mengolah data menjadi sebuah informasi yang tepat, akurat, berkualitas serta dapat dipercaya bagi penggunanya. Hubungan kemampuan teknik personal terhadap efektivitas penggunaan sistem informasi akuntansi, dimana kemampuan teknik personal merupakan salah satu faktor yang mempengaruhi kinerja SIA. Secara umum kemampuan teknik personal sangat dibutuhkan, dimana kemampuan teknik personal akan menunjukan sejauh mana kualitas pribadi seseorang dalam mengoperasikan sebuah sistem akuntansi.PenelitianRuth (2018), meneliti 
tentang Pengaruh Kemampuan Teknik Personal, Pelatihan dan Pendidikan terhadap Efektivitas Penggunaan SIA.

Menurut Lembaga Pemerdayaan Lembaga Perkreditan Desa (LPLPD) Provinsi Bali (2014) Lembaga Perkreditan Desa merupakan salah satu lembaga keuangan yang telah menggunakan sistem informasi akuntansi dalam pengolahan data dan transaksinya. Berdasarkan Peraturan Daerah Bali No.4 Tahun 2012 LPD adalah salah satu unsur kelembagaan Desa Pakraman yang menjalankan fungsi keuangan Desa Pakraman untuk mengelola potensi keuangan Desa Pakraman. Penggunaan sistem informasi akuntansi pada LPD berperan dalam memudahkan karyawan untuk pemprosesan data agar lebih praktis. Berdasarkan data yang diperoleh, Kabupaten Gianyar dikelompokkan menjadi 2 Lembaga Pemerdayaan Lembaga Peerkreditan Desa (LPLPD) yaitu LPLPD Gianyar dan LPLPD Tegallalang. Dari data LPLPD Tegallalang, LPD Kecamatan Ubud terdiri dari 29 LPD. Lokasi penelitian pada LPD Kecamatan Ubud dipilih karena dari segi ekonomi masyarakat lebih cenderung bergerak dalam bidang perdagangan sehingga keberadaan LPD sangat diperlukan untuk membantu permodalan dalam usaha. Selain itu, perkembangan LPD di Kecamatan Ubud sangat berkembang maka sistem informasi akuntansi yang efektif sangat penting untuk meningkatkan pelayanan kepada nasabah dan untuk pemproses data transaksi yang lebih cepat, akurat dan tepat waktu sehingga LPD di Kecamata Ubud mampu menghadapi persaingan yang telah cukup ketat.

Tujuan penelitian ini adalah untuk menganalisis pengaruh kecanggihan teknologi informasi dan kemampuan teknik personal terhadap efektivitas penggunaan sistem informasi akuntansi. Adapun alasan yang mendasari bahwa penelitian ini perlu dilakukan adalah kondisi perkembangan menuntut lembaga keuangan terutama LPD untuk dapat memanfaatkan dukungan teknologi informasi dalam operasional usahanya. Selain itu 
kondisi persaingan yang semakin kompetetif dengan lembaga keuangan selain LPD seperti KSP dan Bank yang berkembang serta faktor- faktor individu yang berbeda mempengaruhi terjadinya kesalahan pengoperasian sistem informasi yang mengakibatkan penggunaan sistem informasi menjadi tidak efektif. Berdasarkan uraian diatas maka rumusan hipotesis sebagai berikut :

\section{H1 : Kecanggihan Teknologi Informasi berpengaruh Terhadap Efektivitas Penggunaan Sistem Informasi Akuntansi}

Kecangihan teknologi informasi adalah sebagai suatu kontruksi yang mengacu pada penggunaan alam, kompleksitas dan saling ketergantungan teknologi informasi dan manajemen dalam suatu organisasi (Ratnaningsih, 2014). Hubungan kecanggihan teknologi informasi dan efektifitas sistem informasi akuntansi dapat dijelaskan dengan pemikiran bahwa sistem yang memiliki kecanggihan yang baik akan membantu perusahaan dalam menghasilkan informasi yang cepat dan akurat dalam pembuatan keputusan yang efektif.

Hubungan kecanggihan teknologi informasi dan efektivitas sistem informasi akuntansi dapat dijelaskan dengan pemikiran bahwa sistem yang memiliki kecanggihan informasi yang baik akan membantu perusahaan menghasilkan informasi yang cepat dan akurat untuk pembuatan keputusan yang efektif (Dwitraani, 2017).

Teknologi adalah suatu pengembangan dari aplikasi atau alat, baik berupa mesin, material hingga proses yang membantu manusia dalam mengerjakan beberapa pekerjaan dan menyelesaikan masalah. Dengan kata lain, teknologi merupakan hasil upaya manusia untuk mempermudah berbagai proses 
yang dilakukan oleh manusia. Sedangkan informasi adalah hasil dari proses yang disampaikan dalam berbagai bentuk yang dapat di manfaatkan atau dimengerti oleh manusia. Dari pengertian tersebut, dapat disimpulkan bahwa teknologi informasi adalah suatu alat yang bermanfaat untuk mengolah data, memproses, menyusun, mengatur, mendapatkan data yang menghasilkan informasi yang akurat dan berkualitas.

\section{H2 : Kemampuan Teknik Personal berpengaruh Terhadap Penggunaan Efektivitas}

\section{Sistem Informasi Akuntansi}

Kemampuan teknik personal dalam mengoperasikan suatu sistem informasi akuntansi sangat diperlukan untuk mengurangi kesalahan maupun kegagalan pengoperasian sistem. Keberhasilan dalam pengembangan sistem informasi sangatlah bergantung pada kesesuaian antara analisis sistem, dan pemakai sistem (Neely dan Cook, 2011). Pengguna yang tidak memiliki kemampuan memadai menyebabkan pengguna dapat memberikan keputusan yang salah, karena pada dasarnya user tersebut kurang memahami besarnya dampak dari keputusan yang diambilnya (Hasan, 2017).

Hasil dari penelitian Hutama (2017) menghasilkan kemampuan teknik personal berpengaruh secara signifikan terhadap kinerja sistem informasi akuntansi. Fani, dkk. (2015), Wilayanti (2016), Yesa (2016), dan Suartika (2017) juga mendapatkan hasil yang sama, dengan kata lain kemampuan teknik personal dilihat dari bagaimana individu dalam mengoptimalkan sistem untuk mempermudah seseorang dalam mengerjakan sesuatu, maka akan mampu memberikan pengaruh yang baik untuk meningkatkan efektivitas SIA.

\section{METODE PENELITIAN}

\section{Desain Penelitian}


Dalam penelitian ini akan menganalisis mengenai Pengaruh Kecanggihan Teknologi Informasi dan Kemampuan Teknik Personal, terhadap Efektivitas Penggunaan Sistem Informasi Akuntansi.

Pada era globalisasi saat ini menimbulkan persaingan yang semakin ketat antar pelaku bisnis, sehingga menuntut organisasi dalam sebuah perusahaan ataupun instansi pemerintah menjadi sangat bergantung pada teknologi. Keberhasilan sistem informasi suatu perusahaan ataupun instansi pemerintah akan tergantung dari bagaimana sistem itu dijalankan oleh individu yang memiliki kinerja dalam pelaksanaannya, kemudahan sistem itu bagi para pemakainya, dan pemanfaatan teknologi yang digunakan. Jaman serba teknologi seperti sekarang ini pasti memerlukan sebuah teknologi yang dapat membantu semua kegiatan terutama dalam kegiatan keuangan. Organisasi atau perusahaan pasti sangat memerlukan sebuah informasi untuk membuat suatu keputusan yang efektif.

Tujuan dalam penyusunan suatu SIA antara lain untuk menyediakan informasi bagi pengelolaan kegiatan keuangan, memperbaiki informasi yang dihasilkan oleh sistem yang telah ada. Sistem informasi akuntansi memberi kesempatan bagi pembisnis untuk meningkatkan efisiensi dan efektivitas dalam pengambilan keputusan sehingga memungkinkan perusahaan memperoleh keunggulan kompetitif (Edison et al., 2012).

Kemampuan teknik personal dalam pengunaan informasi pada suatu perusahaan, dapat dilihat dari kemudahan pemakai dalam mengidentifikasi data, mengakses data dan menginterpretasikan data tersebut. Kemampuan teknik personal akuntansi yang baik akan mendorong pemakai untuk menggunakan sistem informasi akuntansi sehingga kinerja sistem informasi akan lebih tinggi. Dalam perusahaan yang menggunakan sistem informasi akuntansi terkomputerisasi, kemampuan pengoperasian sistem seorang user sangat 
dibutuhkan. User yang mahir dan memahami sistem akan berpengaruh pada kinerja yang dihasilkan dari sistem tersebut.

Kerangka Pemikiran

Gambar 1

Pengaruh Kecanggihan Teknologi Informasi dan Kemampuan Teknik Personal Terhadap Efektivitas Penggunaan Sistem Informasi Akuntansi

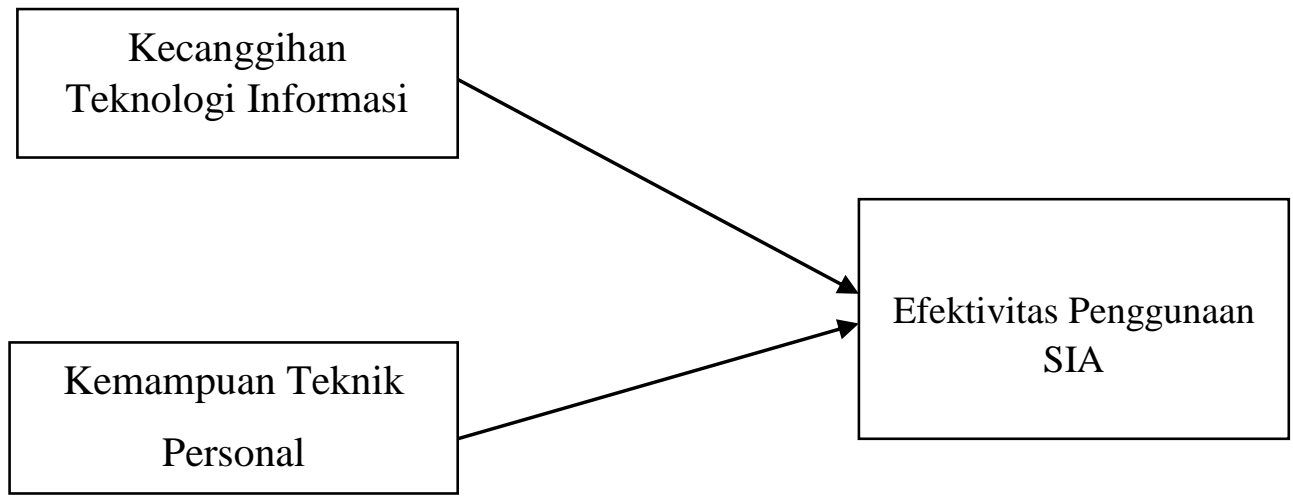

\section{Sumber : Hasil Pemikiran Peneliti 2019}

Penelitian dilakukan di LPD Kecamatan Ubud Kabupaten Gianyar, Bali. Pemilihan tempat penelitian di kecamatan ubud dikarenakan dari segi ekonomi masyarakat lebih cenderung bergerak dalam bidang perdagangan. Jenis data yang digunakan dalam penelitian ini adalah data Kualitatif dan data Kuantitatif sedangkan Sumber data yang digunakan dalam penelitian ini adalah data primer, yaitu data yang diperoleh langsung dari sumbernya, diamati, dicatat untuk pertama kalinya. Data primer meliputi observasi, hasil wawancara dan jawab kuesioner responden pada pegawai LPD yang menggunakan SIA. Teknik pengumpulan data yang digunakan dalam penelitian ini adalah Observasi, wawancara, Dokumentasi dan Kuesioner. Populasi dalam penelitian ini adalah seluruh LPD di Kecamatan Ubud yang yang terdaftar di LPLPD Tegallalang dimana Kabupaten Gianyar dikelompokan menjadi 2 Lembaga Pemerdayaan Lembaga Peerkreditan Desa (LPLPD) yaitu LPLPD Gianyar dan LPLPD Tegallalang yang berjumlah 29 LPD. Sampel 
dalam penelitian ini adalah semua pegawai bagian akuntansi dan keuangan yang bekerja pada LPD di Kecamatan Ubud sebanyak 87 orang responden, dengan berdasarkan kriteria sebagai berikut: (1) Seluruh LPD di Kecamatan Ubud yang terdaftar dan masih aktif di LPLPD Kabupaten Gianyar, (2) Kepala, kasir, dan staf karyawan bagian keuangan atau akuntansiyang berada pada LPD di Kecamatan Ubud.

\section{HASIL DAN PEMBAHASAN}

Pengujian hipotesis dilakukan untuk menguji hipotesis yang diajukan. Hipotesis yang diajukan dalam penelitian ini terkait variabel penelitian. Analisis regresi berganda dipilih untuk menganalisis pengujian hipotesis dalam penelitian ini. Berikut ini hasil analisis regresi berganda yang dilakukan dengan menggunakan program IBM SPSS Statistics 23.0.

\section{Tabel 1}

Hasil Uji Regresi Linear Berganda

Coefficients $^{\mathbf{a}}$

\begin{tabular}{|c|c|c|c|c|c|}
\hline \multirow[t]{2}{*}{ Model } & \multicolumn{2}{|c|}{$\begin{array}{c}\text { Unstandardized } \\
\text { Coefficients }\end{array}$} & \multirow{2}{*}{\begin{tabular}{|c}
$\begin{array}{l}\text { Standardized } \\
\text { Coefficients }\end{array}$ \\
Beta
\end{tabular}} & \multirow[t]{2}{*}{$\mathrm{t}$} & \multirow[t]{2}{*}{ Sig. } \\
\hline & B & Std. Error & & & \\
\hline (Constant) & 1.532 & 1.889 & & .811 & .420 \\
\hline $\mathrm{X} 1$ & 248 & .099 & .253 & 2.512 & .014 \\
\hline $\mathrm{X} 2$ & .228 & .087 & .233 & 2.613 & .011 \\
\hline
\end{tabular}

Dengan menggunakan Tabel 1 maka dapat diperoleh persamaan regresi linier berganda sebagai berikut.

Efektivitas pengguna SIA $(\mathrm{Y})=1,523+0,253\left(\mathrm{X}_{1}\right)+0,233\left(\mathrm{X}_{2}\right)+\varepsilon \mathrm{i}$

Berdasarkan hasil penelitian diketahui bahwa koefisien regresi untuk variabel independen kecanggihan teknilogi informasi (X1) bernilai positif sebesar 0,253, dengan nilai t sebesar 2,512 dan sig 0,014<0,05. Yang artinya kecanggihan teknologi informasi berpengaruh terhadap efektivitas penggunaan sistem informasi akuntansi. Hasil penelitian 
mengandung arti bahwa semakin tinggi kecanggihan teknologi informasi maka akan semakin meningkat efektivitas penggunaan sistem informasi akuntansi di LPD Sekecamatan Ubud Gianyar, begitu juga sebaliknya.

Menurut Maharsi (2000) bahwa teknologi informasi merupakan perpaduan antara teknologi komputer dan telekomunikasi dengan teknologi lainnya. Teknologi informasi dipakai dalam sistem informasi organisasi untuk menyediakan informasi bagi para pemakai dalam rangka pengambilan keputusan. Kecanggihan teknologi informasi terhadap efektivitas penggunaan sistem informasi akuntansi dapat dijelaskan dengan pemikiran bahwa sistem yang memiliki kecanggihan yang baik akan membantu perusahaan dalam menghasilkan informasi yang cepat dan akurat dalam pembuatan keputusan yang efektif.

Hasil penelitian ini juga mendukung penelitian sebelumnya yang dilakukan oleh Krisna (2018). Hasil dari penelitian ini menunjukan bahwa variabel kecanggihan teknologi informasi berpengaruh positif dan signifikan terhadap efektivitas penggunaan sistem informasi akuntansi. Berdasarakan pernyataan tersebut dapat ditarik kesimpulan bahwa kecanggihan teknologi informasi memiliki pengaruh terhadap efektivitas penggunaan sistem informasi akuntansi.

Berdasarkan hasil penelitian diketahui bahwa koefisien regresi untuk variabel kemampuan teknik personal (X2) bernilai positif sebesar 0,233 , dengan nilai t sebesar 2,613 dan sig $0,011<0,05$. Yang artinya kemampuan teknik personal berpengaruh terhadap efektivitas penggunaan sistem informasi akuntansi. Hasil penelitian mengandung arti bahwa semakin tinggi kemampuan teknik personal maka akan semakin meningkat efektivitas penggunaan sistem informasi akuntansi di LPD Se-kecamatan Ubud Gianyar, begitu juga sebaliknya. 
Menurut Yullian (2011) Kemampuan teknik personal dapat diartikan sebagai kemampuan seseorang dalam mengoperasikan sistem dalam mengolah data menjadi sebuah informasi yang tepat, akurat, berkualitas serta dapat dipercaya bagi penggunanya. Kemampuan teknik personal pemakai sistem informasi berperan penting dalam pengembangan sistem informasi untuk dapat menghasilkan informasi guna menciptakan laporan perencanaan yang akurat.

Hasil penelitian ini mendukung penelitian sebelumnya yang dilakukan oleh Ruth (2018), hasil penelitian ini menjelaskan bahwa kemampuan teknik personal berpengaruh positif signifikan terhadap efektivitas penggunaan SIA pada Rumah Sakit di Kabupaten Badung. Berdasarakan pernyataan tersebut dapat ditarik kesimpulan bahwa kemampuan teknik personal memiliki pengaruh terhadap efektivitas penggunaan sistem informasi akuntansi.

\section{SIMPULAN DAN SARAN}

Berdasarkan hasil pembahasan penelitian dapat disimpulkan sebagai berikut: (1) Kecanggihan Teknologi informasi berpengaruh positif dan signifikan terhadap efektivitas penggunaan sistem informasi akuntansi di LPD Kecamatan Ubud. Maka sistem yang memiliki kecanggihan informasi yang baik akan membantu perusahaan menghasilkan informasi yang cepat dan akurat untuk pembuatan keputusan yang efektif dan akan mengalami peningkatan. (2) Kemampuan teknik personal berpengaruh positif dan signifikan terhadap terhadap efektivitas penggunaan sistem informasi akuntansi di LPD Kecamatan Ubud. Maka dengan adanya kemampuan teknik personal akan membantu pemakai untuk menciptakan laporan yang akurat, sehingga semakin tinggi tingkat kemampuan teknik personal maka efektivitas penggunaan sistem semakin meningkat. 
Berdasarkan pembahasan hasil penelitian, kesimpulan berikut beberapa saran yang dapat diberikan: (1) Hasil penelitian ini diharapkan dapat memberikan masukan terhadap pemilik perusahaan, dimana harus lebih meperhatikan kecanggihan teknologi informasi pada perusahaan, dengan cara mengkaji ulang pada setiap komputer yang digunakan oleh pengguna komputer. Kecanggihan teknologi informasi khususnya pengguna komputer yang didukung dengan jaringan internet harus selalu ditingkatkan. Pengguna dan pemelihara teknologi informasi harus selalu diperhatikan agar memudahkan pekerjaan pegawai dan mengurangi kelemahan-kelemahan yang mungkin terjadi. (2) Hasil penelitian ini diharapkan dapat memberikan masukan terhadap pemilik perusahaan, dimana harus lebih memperhatikan kemampuan teknik personal pemakai, dengan cara memberikan masukan pada setiap karyawan agar dapat menguasai penggunaan sistem berbasis komputer, dan pada saat melakukan pelaporan keuangan pemakai bisa lebih akurat dalam melaporkan keuangannya kepada pemilik perusahaan.

\section{DAFTAR PUSTAKA}

Almilia, Luciana Spica dan Briliantien. 2007. Faktor-faktor yang Mempengaruhi Kinerja Sistem Informasi Akuntansi pada Bank Umum Pemerintah di Wilayah Surabaya dan Siduarjo. Jurnal Ilmiah. STIE Perbanas. Surabaya.

Alsarayreh, M.N.O.A.A., Jawabreh, M.M.F. Jaradat, dan S.A Alamro. 2011. Technological Impacts on Effectiveness of Acccounting Information Systems (AIS) Applied by Aqaba Tourist Hotels. European Journal of Scientific Research. Vol 59. No. 3 : 361-369.

Anggraeni, Nova. Retnadi. Eko, Kurniawati, Rina. 2012. Perancangan Sistem Informasi Simpan Pinjam di KUD Mandiri Bayongbong. Jurnal Algoritma. Sekolah Tinggi Teknologi Garut, Indonesia.

Aviana, Putu Mega Selvya. 2012. Penerapan Pengendalian Internal dalam Sistem Informasi Akuntansi berbasis komputer. Jurnal Ilmiah Mahasiswa akuntansi. 1 (4), pp: 65-70.

Dwijayanthi, Diah Maha dan Dharmadiaksa, I.B. 2013. Pengaruh Insentif, Tingkat Pendidikan, Pelatihan dan pengalaman Kerja Pada Kinerja Individu Penggunaan 
Sistem Informasi Akuntansi SKPD Dispenda Kota Denpasar. E-Jurnal Akuntansi Universitas Udayana. 4.(2), h: 332-344.

Dwinda Kharisma, Made dan Dharmadiaksa, Ida Bagus. 2015. Pengaruh Keterlibatan Pengguna dan Ukuran Organisasi terhadap efektifitas pengguna sitem informasi akuntansi dengan kapabilitas personal sitem informasi sebagai variabel pemoderasii di PT Bank Sinar Harapan Bali Denpasar.E-Jurnal Akuntansi Universitas Udayana 10(3), h: 867-881.

Dyah Nastiti, Anugraheni. 2013. Pengaruh Pendidikan, Pelatihan dan Pengalaman Kerja terhadap Kualitas Penyajian Informasi Akuntansi (Studi Kasus pada PT. Bank Rakyat Indonesia di Kota Magelang. E-Jurnal Akuntansi Universitas Dian Nuswantoro. h: 1-14.

Downes, A., \& Barclay, N. (2008). The Role of Performance Management in Organizations. An excerpt from The Rational Guide to Planning with Microsoft Office Performance Point Server 2007, Information Systems Research Mann Publishing Group. 42(6), pp: 8-12.

El louadi, M. (1998). The relationship among organisation structure, information technology and information processing in small Canadian firms. Canadian Journal of Administrative Science. 15(2), pp: 99-180.

Fani, Luh Nanda Yogita. 2015. Pengaruh kecanggihan teknologi informasi, Kemampuan Teknik Pemakai, dan Dukungan Manajemen Puncak Terhadap Kinerja SIA Studi Empiris pada PT PLN (Persero) Area Bali Utara (Kantor Pusat). E-Journal Undiksha.3(1), h: 1-12.

Irma Diana Putri. 2014. Pengaruh Kemampuan Teknik Personal, Program Pelatihan dan Pendidikan Pemakai, Insentif dan Partisipasi Manajemen pada Kinerja Penerapan Sistem Informasi Akuntansi. Skripsi. Jurusan Akuntansi Universitas Udayana.

Jumaili. (2005Sekuritas ). Kepercayaan terhadap teknologi sistem informasi akuntansi terhadap kinerja individual pegawai PT.KIM ENG Indonesia. E Journal Ekonomi Universitas Gunadarma.

Lanidwidyanti. (2010). Pengaruh hubungajn kerja, pengalaman kerja, dan motivasi kerja terhadap kinerja karyawan Bank Central Asia Cabang Borobudur, Malang. EJournal Akuntansi Universitas Udayana.

Lubis. (2013). Pengaruh sistem informasi berbasis computer dan kepercayaan terhadap kinerja individual. Jurnal Riset Akuntansi Dan Bisnis Vol 13.

Jogianto, H. (2011). Metodologi penelitian bisnis.Yogyakarta: BPFE

Komara, A. (2006). Analisis faktor-faktor yang mempengaruhi kinerja sistem informasi akuntansi. jurnal Maksi. Vol.6. 
Kristiani,W. (2012). Analisis Pengaruh Efektivitas Teknologi Informasi Akuntansi Terhadap Kinerja Individual Pegawai PT. KIM ENG Sekuritas Indonesia, Jurusan Akuntansi, Fakultas Ekonomi Universitas Gunadarma.

Mardiana, Putra. (2014). Analisis faktor- faktor yang mempengaruhi kinerja sistem informasi akuntansi pada LPD. Journal Akuntansi Universitas Ganesha. Vol 2 No 1 .

Lesmana, Desy. 2011. Pengaruh Penganggaran Partisipatif, Sistem Pengukuran Kinerja dan Kompensasi Insentif terhadap Kinerja Manajerial Perguruan Tinggi Swasta di Palembang. Jurnal Ekonomi dan Informasi Akuntansi, 1(3), h: 238-252.

LPLPD Provinsi Bali. 2015. Pelatihan Standarisasi Karyawan LPD Kabupaten/ Kota se Bali.

Ratnaningsih, Kadek Indah dan Agung Suaryana, I Gusti Ngurah. 2014. Pengaruh Kecanggihan Teknologi Informasi, Partisipasi Manajemen, dan Pengetahuan Manajer Akuntansi Pada Efektivitas Sistem Informasi Akuntansi.E-Jurnal Akuntansi Universitas Udayana 6(1), h: 1-16.

Ratnaningsih, Kadek Indah., dan Agung Suaryana, I Gst. Ngurah. 2014. Pengaruh Kecanggihan Teknologi Informasi, Partisipasi Manajemen, Dan Pengetahuan Manajer Akuntansi Pada Efektivitas Sistem Informasi Akuntansi. E- Jurnal Akuntansi Universitas Udayana, 6(1): h: 1-16.

Rokhman, Syaiful. 2016. Pengaruh Kecanggihan Teknologi Informasi, Partisipasi Manajemen, Pengetahuan Manajer Akuntansi, Dan Komitmen Organisasional Pada Efektifitas Sistem Informasi Akuntansi (Studi Empiris Pada Hotel Berbintang Di Karisidenan Pati). Dissertasi. Universitas Muria Kudus.

Septianingrum Putri Aryani, P. 2014. Pengaruh Dukungan Top Management, Kemampuan Pengguna, Serta Adanya Pelatihan Dan Pendidikan Pengguna Terhadap Kinerja Sistem Informasi Akuntansi (Studi Kasus Pada BPJS Ketenagakerjaan Semarang dan D.I Yogyakarta). Dissertasi. Fakultas Ekonomi Universitas Negri Yogyakarta.

Setyawan, Hendra. 2013. Pengaruh Kualitas Informasi Kemampuan Teknik Personal Sistem Informasi, Pelatihan dan Pendidikan Pemakai Sistem Terhadap Kinerja Sistem Informasi (Study Empiris Pada Pt. PLN Jawa Timur Distribusi Area Jember). Skripsi Fakultas Ekonomi Universitas Jember.

Seviani, Evi. 2017. Pengaruh Kecanggihan Teknologi Informasi, Partisipasi Manajemen, Dan Pengetahuan Manajer Akuntansi Pada Efektivitas Sistem Informasi Akuntansi (Survei Pada Hotel Berbintang 3 Dan 4 Di Yogyakarta). Dissertasi Fakultas Ekonomi Universitas Muhammadiyah Yogyakarta.

Wigyaringtyas, Tuning Mey. 2014. Analisis Faktor-Faktor yang Mempengaruhi Minat Penggunaan Sistem Informasi Terkomputerisasi (Studi pada KSP di Kab. Semarang). Dissertasi. Program Studi Akuntansi Fakultas Ekonomi dan Bisnis Universitas Kristen Satya Wacana. 
Wilayanti, Ni Wayan., Dharmadiaksa IB. 2016. Keterlibatan dan Kemampuan Teknik Personal Pada Efektivitas Penggunaan Sistem Informasi Akuntansi. E-Jurnal Akuntansi Universitas Udayana, 15(2): h: 1310-1337.

Windha F.K, A.A Istri., dan Dharmadiaksa, IB. 2013. Pengaruh Kinerja Individual Karyawan Terhadap Efektivitas Penggunaan Sistem Informasi Akuntansi. EJurnal Akuntansi Universitas Udayana, 5(3): h: 690-706.

Yesa, Teddy Arrahman Putra. 2016. Pengaruh Partisipasi Pemakai dan Kemampuan Teknik Personal Akuntansi Terhadap Kinerja Sistem Informasi Akuntansi (Studi Empiris BUMN pada Kota Padang Provinsi Sumatera Barat). Jurnal Akuntansi $4(2)$.

Zare, I. 2012. Study of Effect of Accounting Information System and Softwares on Qualitative Features of Accounting Information. Journal of Management Science and Business Research, 1(4): pp: 1-12. 